\title{
Keterlibatan Guru Pendidikan Agama Islam dalam Melakukan Layanan Spiritual terhadap Siswa yang Bermasalah di SMAN X Bandung
}

\author{
Revan Dwi Erlangga*, Nan Rahminawati \\ Prodi Pendidikan Agama Islam, Fakultas Tarbiyah dan Keguruan, \\ Universitas Islam Bandung, Indonesia. \\ *derevan1234@gmail.com,nnan_rahminawati@yahoo.com
}

\begin{abstract}
Islamic Religious Education (PAI) is a compulsory subject given to students at the secondary education level. At SMAN X Bandung, PAI teachers besides teaching also have the task of encouraging students to have a source of religious guidance in solving the problems they are facing, through a spiritual service. This is stated in the Principal's Decree. This research is an empirical research using qualitative descriptive method. This qualitative research uses theoretical and empirical studies presented in the form of narrative texts to clearly describe how the process of spiritual service for students with problems is. The technique used in this research is observation method, interview method, and documentation method. The results of the study indicate that: (a) Regulations set by the principal are the basis for involving PAI teachers to provide spiritual services to troubled students as a manifestation of achieving the school's vision in shaping the noble character of students (b) PAI teachers take various steps to provide customized spiritual services with the internal and external conditions of the problem child. (c) Coordination is carried out between PAI teachers and BK teachers in handling problematic students through horizontal coordination which also involves the homeroom teacher as the person in charge of students at school.
\end{abstract}

Keywords: School Policy, Spiritual Service, Islamic Education Teachers.

Abstrak. Pendidikan Agama Islam (PAI) merupakan mata pelajaran wajib yang diberikan kepada peserta didik pada jenjang pendidikan menengah. Di SMAN X Bandung, guru PAI selain mengajar juga memilki tugas mendorong siswa memiliki sumber pegangan agama dalam menyelesaikan masalah yang sedang dihadapi, melalui suatu layanan spiritual. Hal tersebut tertuang dalam Surat Keputusan Kepala Sekolah. Penelitian ini merupakan penelitian empirik dengan menggunakan metode deskriptif kualitatif. Penelitian kualitatif ini menggunakan kajian teoritis dan empiris yang disajikan dalam bentuk teks bersifat naratif untuk menjabarkan secara jelas bagaimana proses layanan spiritual bagi siswa bermasalah. Teknik yang digunakan dalam penelitian ini menggunakan metode observasi, metode wawancara, dan metode dokumentasi. Hasil penelitian menunjukkan bahwa: (a) Regulasi yang ditetapkan Kepala Sekolah menjadi dasar pelibatan guru PAI melakukan layanan spiritual terhadap siswa bermasalah sebagai salah satu perwujudan pencapaian visi sekolah dalam membentuk akhlak mulia peserta didik (b) Guru PAI melakukan berbagai langkah pemberian layanan spiritual yang disesuaikan dengan kondisi internal dan eksternal anak yang bermasalah. (c) Dilakukan koordinasi antara guru PAI dengan guru BK dalam penanganan siswa bermasalah melalui koordinasi secara horizontal yang juga melibatkan wali kelas sebagai penanggung jawab siswa di sekolah.

Kata Kunci: Kebijakan Sekolah, Layanan Spiritual, Guru PAI. 


\section{A. Pendahuluan}

Pendidikan Agama merupakan pendidikan yang diberikan kepada peserta didik berupa pengetahuan dan skill dalam membentuk sikap, akhlak, dan kepribadian sesuai dengan ajaran dan norma-norma agama. Dalam undang-undang (1) peserta didik mempunyai hak untuk mendapatkan pendidikan agama sesuai dengan agama yang dianutnya. Hal tersebut ditegaskan dalam Peraturan Pemerintah (2) yang menyebutkan bahwa setiap satuan pendidikan disemua jalur, jenjang, dan jenis pendidikan berkewajiban menyelenggarakan pendidikan agama baik dalam institusi negeri maupun swasta.

Pendidikan Agama Islam merupakan upaya untuk menyiapkan peserta didik agar mengenal, mengimani, memahami, bertakwa, berkarakter mulia, serta mengamalkan ajaran agama islam dari Al-Qur'an dan Sunnah melalui kegiatan bimbingan, pengajaran, pelatihan, dan lain sebaginya (3). Pendidikan Agama Islam harus diajarkan oleh pendidik atau guru yang kompeten dalam mengajarkan agama islam. Karena menurut Mulyadi (4) Guru Pendidikan Agama Islam memiliki tugas tidak hanya sebatas memberikan ilmu keagamaan tetapi juga membantu untuk mendorong siswa memiliki sumber pegangan agama (Religious Reference) dalam menyelesaikan masalah yang sedang dihadapi baik dengan melakukan layanan bimbingan, pelatihan, pengajaran, dan lain sebagainya. Peserta didik juga memerlukan layanan spiritual khusus yang dilakukan oleh guru PAI dalam memecahkan masalah dalam dirinya, agar memiliki pemahaman tentang diri dan lingkungannya, juga pengalaman menentukan arah kehidupannya (5). Selanjutnya, Hamdani Bakran adz-Dzaky menyatakan bahwa layanan spiritual islami sebagai suatu aktivitas memberikan bimbingan, pelajaran, dan pedoman kepada individu (klien) dalam hal bagaimana seharusnya seorang klien mengembangkan potensi akal pikirannya, kejiwaannya, keimanan, dan keyakinan serta dapat menanggulangi problematika hidup dan kehidupannya dengan baik dan benar secara mandiri berdasarkan Al-Quran dan AsSunnah (6).

Disamping kegiatan pembelajaran formal salah satu cara yang bisa dilakukan oleh guru Pendidikan Agama Islam dalam mempersiapkan peserta didik dalam mengimani, memahami, bertakwa, berkarakter mulia, serta mengamalkan ajaran agama islam adalah dengan melakukan layanan spiritual yang berlandaskan Al-Quran dan Sunnah. Aplikasi dari layanan spiritual ini bemacam-macam, ada yang dilakukan dengan cara konsultasi secara keagamaan atau melakukan pembiasaan kegiatan keagamaan guna menambah keimanan, keyakinan, arah hidup, dan lain sebagainya pada diri peserta didik (7). Karena kondisi saat ini pelayanan yang diberikan kepada siswa bermasalah hanya sekedar formalitas dalam melaksanakan bimbingan, kurangnya evaluasi dan layanan spiritual dari pihak sekolah dapat menimbulkan masalah-masalah baru yang semakin kompleks pada siswa. layanan spiritual ini harus dijalankan secara optimal dan efektif karena proses layanan yang baik akan berimplikasi signifikan bagi output atau kepuasan siswa dari pelayanan yang diberikan, maka akan ada perubahan yang dilakukan oleh peserta didik ke arah yang baik dan menjadi sebuah kebiasaan apabila kegiatan layanan spiritual dapat berjalan efektif (8).

Berdasarkan data awal yang diperoleh dari hasil wawancara di Sekolah Menengah Atas Negeri X Bandung yang merupakah salah satu sekolah dibawah naungan Pemerintah Provinsi Jawa Barat dengan motto unggulan yakni berilmu, berakhlak, dan berbudaya. Menurut penuturan guru BK di SMAN X Bandung, dalam rangka mencetak generasi yang memiliki akhlak mulia, beliau menyebutkan bahwa setiap guru di SMAN X Bandung sudah senantiasa melakukan proses layanan termasuk oleh guru PAI baik dalam kegiatan belajar mengajar mapun diluar itu sekalipun. Secara explisit sekolah memfasilitasi dengan membuat sistem regulasi layanan yang fleksibel dimana dalam mengatasi siswa yang bermasalah guru PAI di berikan kewenangan untuk senantiasa melakukan layanan spiritual langsung kepada siswa serta bisa berkoordinasi langsung dengan guru BK dan juga wali kelas. Guru PAI diberikan waktu khusus diluar jam mengajar untuk memberikan layanan spiritual terhadap siswa bermasalah, waktunya disesuaikan dengan kebutuhan dari peserta didik. Dan biasanya guru PAI banyak menangani terkait masalah-masalah emosional. Selain itu guru PAI dalam menjalankan perannya melakukan layanan spiritual pihak sekolah membuatkan program umum seperti mengaji bersama, sholat duha bersama untuk meningkatkan kadar keimanan dan ketakwaan para siswa. 
Menurut penuturan guru BK data lain menunjukan bahwa setiap tahunnya hampir $70 \%$ siswa di SMAN X Bandung melakukan bimbingan dengan guru BK dan guru PAI, sebagain besar masalah yang dihadapi siswa berupa pemilihan peminatan, emosional, afirmasi, hingga memilih perguruan tinggi. Kurang dari X\% nya guru BK dan guru PAI lebih menangani terhadap siswa yang bermasalah dalam segi akademik dan sosialnya. Layanan yang dilakukan oleh guru BK dan guru PAI membuahkan hasil yang tidak sia-sia, siswa yang memiliki masalah dalam akademik dan sosialnya terlihat peningkatan sesuai dengan aturan yang diharapkan ditinjau dari catatan evaluasi yang guru BK miliki dengan mayoritas masalahnya bisa diselesaikan dan terdapat perubahan karakter maupun perilaku kepada siswa yang bermasalah.

Secara eksplisit mayoritas di sekolah-sekolah negeri lain dalam menangani siswa bermasalah dibebankan hanya kepada guru BK saja tidak ada bentuk koordinasi yang dilakukan antara guru PAI dan guru BK setiap ada masalah yang ditemukan. Namun di SMAN X Bandung siswa yang bermasalah tidak di nanti-nanti dalam pelayanan, ditambah setiap guru berpegang terhadap tanggung jawab yang telah diamanahi termasuk oleh guru PAI dalam menjalankan perannya dalam melakukan layanan spiritual. layanan spiritual yang dilakukan dapat membantu memecahkan masalah yang di alami oleh siswa sehingga kasus yang dialami oleh siswa di sekolah dapat tertangani dengan baik sesuai dengan arahan dan sudut pandang agama.

Berdasarkan uraian latar belakang di atas, maka ada beberapa perumusan masalah yang akan peneliti bahas dalam penelitian ini diantaranya sebagai berikut.

1. Bagaimana kebijakan yang ditetapkan terkait keterlibatan guru Pendidikan agama Islam dalam melakukan layanan spiritual terhadap siswa bermasalah di SMAN X Bandung.

2. Bagaimana langkah-langkah yang dilakukan oleh guru Pendidikan Agama Islam dalam melakukan layanan spiritual terhadap siswa yang bermasalah di SMAN X Bandung.

3. Bagaimana bentuk koordinasi antara guru Bimbingan konseling dan guru Pendidikan Agama Islam dalam penanganan siswa bermasalah di SMAN X Bandung.

\section{B. Metodologi Penelitian}

\section{Pendekatan Penelitian}

Pendekatan yang akan digunakan dalam penelitian ini adalah pendekatan kualitatif. Peneltian dengan menggunakan pendekatan kualitatif merupakan penelitian yang bermaksud untuk mengkaji dan mendalami fenomena terkait hal yang dialami oleh objek penelitian secara menyeluruh dengan cara mendeskripsikan kata-kata, bahasa pada situasi khusus yang dialami dengan menggunakan metode ilmiah tertentu (9).

Pendekatan kualitatif ini digunakan peneliti untuk mengemukakan secara jelas dan mendalam mengenai kegiatan proses layanan bimbingan di SMAN X Bandung dan mengidentifikasi mengapa layanan bimbingan di SMAN X Bandung melibatkan guru PAI dalam pelaksanaanya, serta dengan menggunakan metode kualitatif ini peneliti dapat mengetahui pengaruh hubungan guru PAI dan guru BK dalam melakukan bimbingan kepada siswa dan mengatahui bagaimana proses evaluasi yang dilakukan oleh guru PAI dan guru BK dalam menindak lanjuti kasus masalah yang dihadapi oleh siswa. Informasi-informasi tersebut dapat ditemukan dan dikupas menggunakan metode kualitatif dengan mendeskripsikan katakata dan bahasa yang didapat dari hasil kegiatan observasi, wawancara, dan dokumentasi yang terjadi dalam kegiatan proses layanan bimbingan di sekolah.

\section{Sumber Data}

Peneliti menggunakan sumber data primer dan sumber data sekunder dalam meneliti.

1. Sumber Informan

Penelitian mengenai implementasi kebijakan sekolah terkait keterlibatan guru PAI melakukan layanan spiritual kepada siswa bermasalah di SMANX Bandung ini peneliti menggunakan sumber Informan sebagai berikut:

a. Guru BK SMAN X Bandung, karena bertanggung jawab dalam mengelola dan melakukan layanan bimbingan terhadap siswa bermasalah di sekolah.

b. Guru Pendidikan Agama Islam SMAN X Bandung, karena sebagai pelaksana kebijakan serta bertanggung jawab dalam proses layanan spiritual di sekolah. 
c. Kepala SMAN X Bandung, karena berperan dalam pembuatan kebijakan di sekolah terkait keterlibatan guru PAI dalam layanan spiritual di SMAN X Bandung.

2. Sumber Data Sekunder

Sumber data sekunder merupakan sumber data yang mendukung penelitian (X). Maka dalam penelitian mengenai implementasi kebijakan sekolah terkait keterlibatan guru PAI melakukan layanan spiritual kepada siswa bermasalah di SMANX Bandung ini peneliti menggunakan sumber data sekunder sebagai berikut:
a. Visi misi dan tujuan SMAN X Bandung
b. Struktur Organisasi SMAN X Bandung
c. Data guru dan siswa di SMAN X Bandung

\section{Teknik Pengumpulan Data}

Penelitian kualitatif ini peneliti menggunakan beberapa teknik dalam mengumpulkan data penelitian untuk menghasilkan data yang kongkrit, teknik tersebut diantaranya sebagai berikut:

1. Metode Observasi

Dalam penelitian ini metode observasi dilakukan dengan cara mengamati proses pelaksanaan layanan spiritual terhadap siswa bermasalah yang di lakukan oleh guru PAI di sekolah sesuai kebijakan regulasi yang berlaku. Metode observasi dalam penelitian ini digunakan guna memperoleh data diantaranya sebagai berikut:

a. Proses layanan spiritual yang dilakukan oleh guru pendidikan agama Islam di SMAN X Bandung.

b. Bentuk koordinasi yang dilakukan guru pendidikan agama islam dengan guru BK di sekolah dalam menangani siswa bermasalah dalam melakukan layanan spiritual.

c. Kebijakan regulasi yang digulirkan SMAN X Bandung terkait keterlibatan guru PAI dalam melakukan layanan spiritual.

Peneliti melakukan observasi secara langsung dengan melakukan mengamatan ke SMAN X Bandung untuk mengamati fenomena yang diteliti. Hasil observasi ini dicatat dalam catatan lapangan, isi catatan tersebut berupa periswa yang terjadi, interkasi, proses, dan sistem serta implementasi kebijaknnya.

2. Metode Wawancara

Metode wawancara dilakukan dengan berdialog secara langsung dengan beberapa narasumber diantaranya sebagai berikut;

a. Kepala sekolah sebagai pemegang dan pembuat kebijakan, wawancara tersebut dilakukan untuk mengkaji apa, mengapa, dan bagaimana kebijakan tersebut dibuat dan diimplementasikan.

b. Guru BK sebagai koordinator penanganan siswa bermasalah di sekolah, wawancara ini untuk menemukan koordinasi yang dilaksanakan dengan guru PAI.

c. Guru PAI sebagai orang yang melakukan regulasi kebijakan tersebut, wawancara ini dilakukan untuk mengidentifikasi langkah-langkah yang dilakukan oleh guru PAI dalam melakukan layanan spiritual terhadap siswa bermasalah di sekolah

Hasil dari wawancara ini dituliskan secara sistematis dan ringkas mulai dari identitas, identifikasi masalah, deskripsi data yang berkaitan dengan tema penelitian.

3. Metode Dokumentasi

Metode dokumentasi merupakan pengamatan yang dilakukan terhadap barang-barang tertulis sepeti catatan, buku, notulensi dan dalin sebagainya. Metode dokumentasi ini digunakan untuk mendapatkan informasi berupa sistem pelaksaan dan gambaran terkait dokumen-dokumen yang diperlukan seperti buku layanan, dan catatan-catatan dalam proses layanan spiritual di sekolah yang dimiliki oleh guru PAI dan guru BK di SMAN $\mathrm{X}$ Bandung.

\section{Teknik Analisis Data}

Analisis data dalam penelitian kualitatif ini dilakukan pada awal sebelum memasuki lapangan, selama dilapangan, dan setelah proses pengumpulan data. Ada tiga komponen utama dalam 
menganalisis data penelitian ini yang dijelaskan sebagai berikut:

1. Pemilihan Data

Dalam penelitian yang peneliti lakukan kegiatan pemilihan data ini dilakukan dengan mengumpulkan, memilih, memilah, serta menganalisis data yang telah didapatkan dalam proses observasi, wawancara, serta kajian dokumentasi yang relevan dengan pengimplementasian kebijakan sekolah, bentuk koordinasi yang dilakukan oleh guru BK dan guru PAI, sera langkah-langkah yang dilakukan dalam melakukan layanan spiritual terhadap siswa bermasalah di SMAN X Bandung. Data yang sudah didapatkan kemudian dikuatkan dengan relevansi teori-teori dari berbagai sumber agar hasil penelitian menjadi lebih komprehensif.

2. Penyajian Data Hasil dari pemilihan data tersebut kemudian disajikan dalam bentuk deskripsi berupa teks yang bersifat naratif. Penyajian data tersebut dilakukan guna memperjelas pemaparan dan mempertegas kesimpulan yang akan diambil. Proses penyajian data dilakukan dengan mengungkapkan data hasil penelitian secara menyeluruh agar mudah dipahami. Data tersebut bisa menggambarkan bagaimana pengimplementasian regulasi sekolah terkait keterlibatan guru PAI dalam melakukan layanan spiritual terhadap siswa bermasalah di SMAN X Bandung mulai dari kebijakan, bentuk koordinasi serta langkahlangkah yang ditempuh guru PAI dalam memberikan layanan spiritual tersebut.

3. Menarik Kesimpulan

Data yang sudah dipilih dan disajikan kemudian dilakukan penyimpulan. Kesimpulan ini berisi temuan yang didideskripsikan suatu objek yang sebelumnya masih belum jelas dari sebuah permasalahan sehingga setelah diteliti menjadi jelas dengan menemukan jawaban dari permasalahn yang dicari. Kesimpulan dari penelitian ini diperoleh dari seluruh kajian bab pada skripsi ini guna memberikan kejelasan berupa kebijakan, bentuk koordinasi, serta langkah-langkah yang dilakukan oleh guru PAI dalam melakukan layanan spiritual dalam pengimplementasian regualsi sekolah terkait keterlibatan guru PAI dalam melakukan layanan spiritual terhadap siswa bermasalah di SMAN X Bandung.

\section{Hasil Penelitian dan Pembahasan}

Regulasi yang ditetapkan terkait keterlibatan guru Pendidikan agama Islam dalam melakukan layanan spiritual terhadap siswa bermasalah di SMAN X Bandung.

SMAN X Bandung memiliki kebijakan yang tertuang dalam Surat Keputusan kepala sekolah tentang pembagian tugas guru dalam mengajar dan bimbingan dengan Nomor SK 896/804SMAN.X/2021 yang menyebutkan bahwa guru PAI diberikan kewenangan untuk membantu mengatasi siswa bermasalah dengan memberikan layanan spiritualitas serta bisa berkoordinasi antara guru BK dan wali kelas. Hal ini dilakukan sekolah agar proses keberjalanan program layanan di sekolah dapat berjalan dengan efektif untuk mencapai tujuan sekolah, hal ini selaras dengan Van Meter dan Horn (11) yang menyebutkan bahwa implementasi dari sebuah regulasi menghubungkan antara tujuan dan realisasi regulasi dilapangan terhadap hasil kegiatan yang diharapkan sekolah.

Dengan Visi SMAN X Bandung adalah dalam membentuk akhlak mulia maka dibuatlah kebijakan terkait keterlibatan guru PAI guna memberikan layanan spiritual untuk membantu siswa bermasalah di sekolah agar membantu sekolah mencapai Visi tersebut, hal ini didukung oleh Wahjosumidjo (12) yang menyebutkan bahwa kebijakan sekolah merupakan faktor pendorong untuk mencapai tujuan sekolah secara efektif dan efisien. Maka apabila kebijakan tersebut tidak dibuat penyelesaian masalah siswa tidak bisa dilakukan secara cepet dan akurat, serta tidak ada nilai spiritualitas yang melekat kepada siswa sehingga pencapaian visi misi SMAN X bandung dalam membentuk akhlak mulia dapat terhambat.

Komunikasi yang baik dalam penyampaian kebijakan serta saran dan masukan dari guru-guru yang terlibat dalam kebijakan ini seperti guru BK dan guru PAI serta dikelola dengan baik oleh sekolah membuat proses pengimplementasian berjalan dengan baik. Di SMAN X tidak memiliki birokrasi yang rumit dalam menjalan dan menginformasikan sebuah kebijakan, karena 
brokrasi yang rumit dapat menyebabkan kelemahan terhadap kebijakan tersebut karena lamanya struktur birokrasi yang ditempuh. Stuktur birokarsi yang dilakukan SMAN X Bandung dalam mengimplementasikan kebijakan tersebut dapat digambarkan melalui bagan berikut.

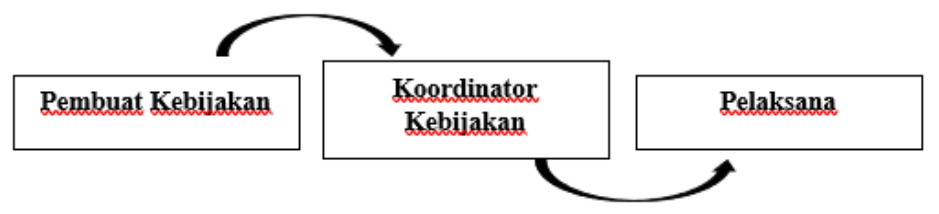

Gambar 1. Struktur Birokrasi Kebijakan

Pembuat kebijakan merupakan pihak stakeholder sekolah baik itu kepala sekolah maupun wakasek, kebijakan tersebut langsung di sosialisasikan kepada guru BK selaku koordinator kebijakan tersebut, dari guru BK diinformasikan kepada pelaksana kebijakan yakni guru PAI dalam memberikan layanan spiritual bagi siswa bermasalah di sekolah, karena struktur birokrasi yang mudah maka proses pengimplementasian kebijakan tersebut bersifat fleksibel dalam berkoordinasi.

Salah satu faktor pendukung dalam proses pengimplementasian kebijakan sekolah adalah sumber daya yang kompeten dan kompetitip dalam menjalankan program kebijakan tersebut. Dalam proses perekrutan sumber daya tersebut baik guru BK dan guru PAI dilakukan secara selektif, di SMAN X Bandung lebih mengutamakan guru BK yang beragama islam agar selaras dalam pelaksanaan kebijakan tersebut. Jika melihat peraturan Mentri Pendidikan Nasional Republik Indonesia Nomor 16 Tahun 2007 tentang standar kualifikasi akademik dan kompetensi guru menyebutkan bahwa standar kualifikasi guru ditentukan kedalam empat hal, kompetensi pedagogik, kepribadian, sosial, dan professional (13), pemilihan guru BK yang beragama islam bukan merupakan rasisme yang dilakukan sekolah, tetapi merupakan suatu langkah yang dilakukan guna menjaga kualitas layanan yang dilakukan oleh guru BK. Serta kinerja dan kualitas guru juga ditentukan oleh kepemimpinan kepala sekolah dalam memberikan motivasi (14). Oleh sebab itu dalam menjalan kebijakan sekolah menurut Edwards (15) kualitas dan kuantitas sumber daya yang kurang mendukung sebuah kebijakan akan menyebabkan pelaksanaan sebuah kebijakan tidak dapat berjalan secara efektif.

Maka regulasi kebijakan di SMAN X Bandung terkait keterlibatan guru pendidikan agama islam dalam menangani siswa bermasalah di sekolah berjalan dengan baik karena melibatkan sumberdaya yang kompeten dibidangnya serta kemudahan dan kelancaran dalam komunikasi dan birokrasi yang menunjang keberjalanan program tersebut untuk mencapai visi misi sekolah dalam membentuk akhlak mulia.

\section{Langkah-langkah yang dilakukan oleh guru Pendidikan Agama Islam dalam melakukan layanan spiritual terhadap siswa yang bermasalah di SMAN X Bandung.}

Layanan spiritual diberikan oleh guru PAI kepada siswa bermasalah di adalah dalam rangka mengimplementasikan kebijakan regulasi yang telah ditetapkan berupa keterlibatan guru PAI dalam menangani siswa bermasalah. Layanan Spiritual yang dilakukan oleh guru PAI di SMAN $\mathrm{X}$ Bandung diberikan dalam rangka membimbing siswa untuk menemukan jalan keluar atas masalah yang dihadapi dalam sudut pandang dan nilai-nilai agama (16), artinya segala masalah yang ada harus melibatkan Allah, bahwa Allah akan menolong dan merespon hambanya yang bertakwa dan senang berdo'a kepada-Nya (17).

Langkah-langkah yang dilakukan oleh guru PAI dalam memberikan layanan spiritual di SMAN X Bandung dilakukan secara conditional baik dalam kegiatan formal seperti belajar mengajar ataupun kegiatan informal lainnya. Langkah-langkah tersebut dapat dijabarkan sebagai berikut:

1. Menemukan atau mendapat laporan dari guru BK terkait siswa yang bermasalah baik masalah akademik, spiritual, bahkan masalah sosial.

2. Mengkaji laporan tersebut baik dari asal-usul, materi, hingga metode yang sesuai dengan masalah tersebut. 
3. Hasil dari kajian tersebut diberitahukan kepada guru BK dan wali kelas untuk membantu mencarikan solusi, disamping itu guru BK mengarahkan langsung siswa tersebut untuk berkomunikasi melakukan layanan dengan guru PAI.

4. Mengevaluasi hasil layanan yang telah diberikan dengan berkoordinasi anatara guru BK dan kelas untuk memonitoring perkembangannya.

5. Melaporkan perkembangan tersebut kepada guru BK dan wali kelas agar menjadi catatan dan bahan laporan kepada pihak sekolah.

Langkah-langkah tersebut dilakukan agar kegiatan proses layanan spiritual kepada siswa dapat terstruktur dan dapat terevaluasi oleh berbagai pihak yang terlibat. Menurut Burhanudin (18) proses tersebut dilakukan sebagai bentuk management dalam rangka merencanakan, mengorganisasikan, memetakan, mengarahkan, serta melakukan pengawasan terhadap proses yang telah dilakukan guna mencapai tujuan yang diharapkan. Langkah yang dilakukan guru PAI di SMAN X Bandung tersebut dengan yang disebutkan oleh Nurul dalam jurnalnya (19) sama membahas dan mengajk untuk menyelesaikan masalahnya dengan pendekatan keagamaan namun berbeda dalam segi teknisnya namun ini tidak menjadi masalah karena di SMAN X Bandung ada kewajiban birokrasi yang harus dilaporkan.

Dalam proses penyampaiannya guru PAI di SMAN X Bandung menggunakan metode cermah baik ketika KBM ataupun kegiatan informal lain seperti kultum dalam acara dan lain sebagainya. Apabila masalah yang dihadapi oleh siswa cukup krusial maka guru PAI membuka layanan khusus secara intens untuk memberikan layanan spiritual tersebut. Selain itu metode yang dilakukan oleh guru PAI dalam memberikan layanan di SMAN X Bandung adalah dengan menggunakan metode keteladanan, memeragakan kehidupan secara riil sehingga siswa belajar, menirukan dan mengintegrasikan dalam kehidupannya (20).

Materi atau nilai-nilai yang diajarkan oleh guru PAI dalam melakukan layanan spiritualitas adalah dengan mengajarkan nilai-nilai keimanan dan ketauhidan agar para siswa paham bagaimana caranya mereka berhubungan baik dengan Allah dan lingkungan sosial mereka disamping materi-materi yang menjadi inti masalah dari para siswa. Dalam proses pemberian layanan spiritual di SMAN X Bandung dilakukan oleh orang-orang yang ahli dibidang spiritualitas, ini sejalan dengan pendapat Misnamar (Misnamar, 1992) terkait syaratsyarat yang harus dimilki dalam memberikan layanan spiritualitas dianataranya:

1. Memiliki keahlian dalam bidang keagamaan.

2. Memiliki sifat dan kepribadian yang berakhlak mulia.

3. Memiliki kemampuan hubungan sosial yang tinggi.

4. Bertaqwa kepada Allah Swt.

Oleh sebab itu keberjalanan layanan spiritualitas di SMAN X Bandung dapat berjalan dengan baik karena sudah terstruktur mulai dari sumberdaya yang kompeten, langkah yang terstruktur, juga kemampuan guru PAI dalam menjalankan kewajiban dengan membina akhlak siswa.

\section{Bentuk koordinasi antara guru Bimbingan konseling dan guru Pendidikan Agama Islam dalam penanganan siswa bermasalah di SMAN X Bandung.}

Koordinasi antara guru BK dan guru PAI dalam menjalankan layanan spiritual bagi siswa bermasalah di SMAN X Bandung berjalan dengan baik. Koordinasi yang muncul menjadi bukti pengimplementasian kebijakan tersebut karena menurut Quade (21) sangat ideal dengan adanya aksi, reaksi, dan interaksi dalam proses pengimplementasian kebijakan tersebut. Bentuk koordinasi yang dibuat antara guru BK dan guru PAI di SMAN X Bandung adalah bentuk horizontal artinya koordinasi antara unit yang sama atau sejajar. Menurut Nathania (dalam Swandhana, 2017) koordinasi horizontal dilakukan dalam rangka untuk memecahkan masalah secara bersama karena diperlukan brainstorming dari semua divisi yang terlibat.

Namun jika koordinasi horizontal tersebut tidak dilakukan maka masalah yang muncul tidak dapat terevaluasi seakan-akan guru PAI dan guru BK bersifat independent. Atau jika koordinasi tersebut dirubah menjadi koordinasi vertikal langsung pelaksana dengan pembuat kebijakan maka proses dalam menangani masalah siswa akan tersendat birokrasi dan mungkin tertindih dan terlupakan akibat pekerjaan yang lain. Koordinasi Horizintal tersebut dilakukan 
secara conditional tanpa ada waktu atau tempat khusus, agar setiap masalah yang muncul cepat tertangani. Dalam proses koordinasi tersebut melibatkan wali kelas sebagai penanggung jawab siswa di sekolah. Bentuk koordinasi tersebut dapat digambarkan melalui bagan berikut:

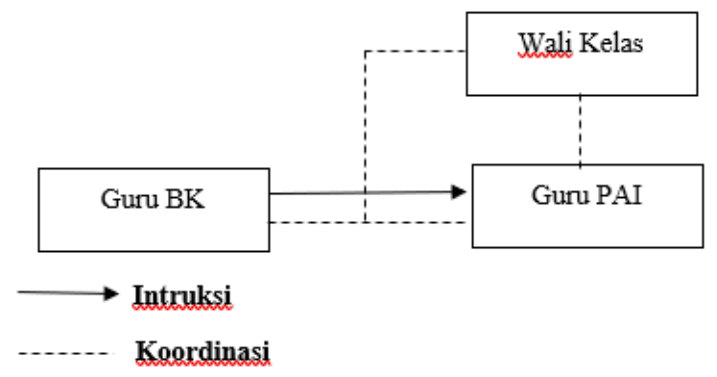

Gambar 2. Bentuk Koordinasi Antara Guru BK dan Guru PAI.

Pada prosesnya hambatan seringkali muncul dalam koordinasi antara guru PAI dan Guru BK diantaranya keterbatasan komunikasi serta layanan yang dilakukan, dan terkendala ketika ada anak yang tidak mau di berikan bimbingan oleh guru PAI karena anak tersebut tidak suka dengan guru PAI yang diarahkan, namun dengan jumlah guru PAI yang cukup banyak memudahkan guru BK untuk mengarahkan kepada guru PAI yang lain. Ini selaras dengan pendapat Nugroho (23) keberhasilan sebuh koordinasi tergantung terhadap kualitas dan kuantitas aktor yang menjalankan bentuk kooordinasi tersebut.

Keberhasilan sebuah kebijakan dapat dipengaruhi oleh komunikasi yang dilakukan antara pelaksana kebijakan (24). Semakin baik dan terstruktur sebuah pola koordinasi maka keberjalanan sebuah kebijakan dapat tertangani dengan baik. Implementasi kebijakan sekolah terkait keterlibatan guru PAI dalam menjalankan layanan spiritual tidak akan berjalan apabila tidak ada koordinasi antara guru PAI dan guru BK, karena menurut Etih (25) harmonisasi antara semua elemen sangat berpengaruh terhadap keberhasilan sebuah kebijakan. Maka koordinasi yang dilakukan guru PAI dan guru BK dalam melakukan layanan kepada siswa bermasalah di SMAN X Bandung dibuat dalam rangka menstimulus keberhasilan kebijakan tersebut.

\section{Kesimpulan}

Berdasarkan pembahasan dalam penelitian ini, peneliti menyimpulkan beberapa hasil penelitian sebagai berikut:

1. Regulasi yang ditetapkan terkait keterlibatan guru Pendidikan agama Islam dalam melakukan layanan spiritual terhadap siswa bermasalah yakni berupa kewenangan dan keleluasaan guru PAI yang diberikan sekolah dalam menangani siswa bermasalah yang tertuang dalam Surat Keputusan kepala sekolah tentang pembagian tugas mengajar dan bimbingan dengan Nomor Surat 896/804-SMAN.X/2021. Kebijakan tersebut dibuat sebagai landasan pelaksanaan pelayanan spiritual yang dilakukan oleh guru PAI.. Dan kebijakan regulasi tersebut dibuat dalam rangka mencapai tujuan serta visi dan misi sekolah. Jika tidak ada kebijakan tersebut maka pelayanan dalam mengatasi siswa bermasalah tidak dapat berjalan dengan lancer dan menghambat pencapaian visi misi sekolah untuk membentuk akhlak mulia.

2. Langkah-langkah yang dilakukan oleh guru Pendidikan Agama Islam dalam melakukan layanan spiritual terhadap siswa yang bermasalah sudah sesuai dengan teori bimbingan spiritual yang telah dijelaskan oleh beberapa ahli namun ada beberapa kekurangan dan beberapa kelebihan dari aplikasi yang telah dilakukan. Langkah-langkah yang dilakukan oleh guru PAI tersebut adalah untuk mengarahkan siswa memecahkan masalah dalam sudut pandang keagamaan serta bisa memberikan masukan serta motivasi-motivasi keagamaan yang sesuai dengan kondisi masalah yang sedang dihadapi, apabila tidak dilakukan oleh guru PAI maka ditakutkan kegiatan layanan kurang berjalan dengan efektif karena kurang pemahanan pembimbing dalam bidang keagamaan. Walaupun banyak teori yang menjelaskan tentang cara dan prosedur layanan bimbingan islami 
namun semuanya sama yakni untuk mendongkrak nilai spiritual peserta didik agar sesuai antara perbuatan, pola hidup dengan ajaran agama yang dianutnya.

3. Bentuk koordinasi antara guru Bimbingan konseling dan guru Pendidikan Agama Islam dalam penanganan siswa bermasalah adalah koordinasi secara horizontal antara guru BK dan guru PAI dengan melibatkan wali kelas sebagai penanggung jawab siswa di sekolah dan membantu mengevaluasi layanan spiritual yang telah dilakukan oleh guru PAI. Koordinasi ini harus dilakukan karena sebagai salah satu bentuk interaksi yang dilakukan antara guru PAI dan guru BK di sekolah untuk mencapai tujuan bersama dalam pengimplementasian kebijakan. Jika koordinasi tersebut tidak dilakukan maka penanganan siswa yang memiliki masalah akan lama tertangani karena tidak terevaluasi baik oleh guru PAI maupun guru BK, serta jika dirubah menjadi koordinasi vertikal maka proses pelayanan akan terkendala oleh lamanya birokrasi.

\section{Acknowledge}

Terimakasih kepada semua pihak yang telah mendukung dan membantu proses penelitian ini. Terutama kepada dosen pembimbing Dr. Nan rahminawati, M.Pd, dan H. Eko Surbiantoro, Drs., M.Pd.I yang telah mencurahkan waktu dan pikirannya untuk membantu menyelesaikan penelitian ini

\section{Daftar Pustaka}

[1] Kementerian Hukum dan HAM Republik Indonesia. Undang-Undang No.20 Tahun 2003 tentang Sistem Pendidikan Nasional. Jakarta; 2003.

[2] Indonesia PR. Peraturan Pemerintah No.55 Tahun 2007 Tentang Pendidikan Agama dan Keagamaan. 2007.

[3] Ramayulis. Metodologi Pendidikan Agama Islam. Jakarta: Kalam Mulia; 2005.

[4] Mulyadi. Bimbingan Konseling Disekolah dan Madrasah. Jakarta: Prenadamedia Group; 2016.

[5] Rohman A. Peran Bimbingan Dan Konseling Islam Dalam Pendidikan. J Pendidik Agama Islam Univ Wahid Hasyim PERAN. 2016;04(01):137-55.

[6] Erhamwilda. Konseling Islami. Psikosain, editor. Yogyakarta; 2019.

[7] Yuriani. Efektivitas Layanan Konseling Spiritual Teistik Dalam Meningkatkan Kecerdasan Adversitas. Sekol Tinggi Agama Buddha Negeri Sriwij Tangerang Banten. 2016;5-24.

[8] Wahidin. Efektivitas Pelaksanaan Program Bimbingan dan Konseling. J Konseling Andi Matappa. 2018;2(2):111-9.

[9] Lexy J. Moleong. Metodelogi Penelitian Kualitatif. Bandung: PT Remaja Rosdakarya; 2000.

[10] Arikunto S. Prosedur Penelitian Suatu Pendekatan Praktek. Jakarta: Rineka Cipta; 2002.

[11] Merilee. S. Grindle. Politics and Policy Implementation In the Third World. New Jersey: Princton University Press; 1980.

[12] Wahjosumidjo. Kepemimpinan Kepala Sekolah Tinjauan Teoritik dan Permasa_lahannya. Jakarta: Rajawali Press; 2005.

[13] Republik Indonesia. Peraturan Menteri Pendidikan Nasional Nomor 16 Tahun 2007 Standar Kualifikasi Akademik dan Kompetensi Guru. Jakarta; 2007.

[14] Sri Setiyati. Pengaruh Kepemimpinan Kepala Sekolah Terhadap Motivasi Kerja dan Kinerja Guru. Ilmu Pendidik J Kaji Teor dan Prakt Kependidikan. 2016;1(2):63-70.

[15] George. C. Edwards III. Public Policy Implementing. Inc JP, editor. London England; 1984.

[16] Marimba AD. Pengantar Filsafat Pendidikan Islam. Bandung: Al-Ma'arifat; 1999.

[17] Mustaffa, M.S. Kaunseling Islam. J Pendidik Univ Teknol Malaysia. 1998;4(1):X-30.

[18] Burhanudin Gesi, Rahmat Laan FL. Manajemen Dan Eksekutif. J Manaj. 2019;3(2):55-66.

[19] Istiani N. Konsep Strategi Theistic Spiritual Dalam Layanan Bimbingan Konseling Dan Psikoterapi Islam. Religia. 2017;20(2):190-206. 
146 | Revan Dwi Erlangga, et al.

[20] Muhaimin. Strategi Belajar Mengajar (Penerapannya dalam Pembelajaran Agama). CV. Citra Media; 1997.

[21] Quade ES. Analysis For Public Decisions. New York: Elsevier Science Publisher; 1984.

[22] Swandhana H. Peranan Komunikasi Horizontal Dalam Peningkatan Kinerja Pada Prime Sauce. PERFORMA J Manaj dan Start-Up Bisnis. 2017;2(2):228-34.

[23] Nugroho AYA. Koordinasi Dan Usaha Koordinasi Dalam Organisasi : Sebuah Kerangka Studi. J Adm Bisnis Unpar. 2012;8(2).

[24] Purwanto. Implementasi Kebijakan Publik Konsep dan Aplikasinya Di Indonesia. Yogyakarta: Gaya Media; 2012.

[25] Etih Henriyani. Problematika Dalam Implementasi Kebijakan Publik. Vol. 1, Jurnal Ilmiah Ilmu Pemerintahan. 2015. p. 1-X. 